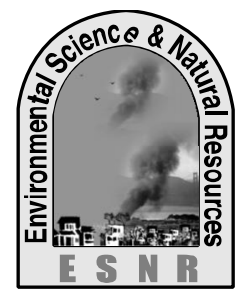

\title{
The Urgency of Studies on Cadmium Manifestation (Cd) in Food Chain
}

\author{
S. A. Mamun ${ }^{1 *}$, R. H. Arif ${ }^{1}$, Z. Parveen ${ }^{2}$, M. Aktar ${ }^{1}$ and M. S. Islam ${ }^{1}$ \\ ${ }^{1}$ Department of Environmental Science and Resource Management, \\ Mawlana Bhashani Science and Technology University, Tangail-1902, Bangladesh \\ ${ }^{2}$ Department of Soil, Water and Environment, University of Dhaka, Dhaka-1000
}

*Corresponding author: shamim084du@gmail.com

\begin{abstract}
Cadmium (Cd) is a heavy metal which is not essential for human body. Cadmium enters into human body mainly through food consumption. Besides industrial wastes, phosphate fertilizers contain $\mathrm{Cd}$ which accumulates gradually in agricultural lands. To produce high quantity of food for about 160 million people of Bangladesh, agricultural lands need to be applied huge amount of fertilizes including TSP which add $\mathrm{Cd}$ to soils. It has been reported that in rice grains the cadmium concentrations were the highest in Bangladesh and Srilanka where the per capita rice intake is high, from a survey on four continents of 12 countries. The intake of these $\mathrm{Cd}$ containing foods may ultimately increase the $\mathrm{Cd}$ concentration in human kidneys and livers which might be related to the enhanced kidney patients in Bangladesh. There is lot of toxic effects of excess $\mathrm{Cd}$ on humans. The present review illustrates the urgency of further studies of $\mathrm{Cd}$ in Bangladesh.
\end{abstract}

Keywords: Cadmium, Food chain, Human health

\section{Introduction}

Bangladesh is one of the most densely populated countries in the world (BBS, 2006). Agriculture plays an important role in the revival of Bangladesh national economy (Ayoub, 1999). The quality of the soil determines the nature of plant ecosystems and the capacity of land to support animal life (Wild, 1996). Agricultural soil contamination with heavy metals through the repeated use of untreated or poorly treated wastewater from establishments and application of chemical fertilizers and different types of pesticides is one of the most severe environmental problems in
Bangladesh (Rahman et al., 2012). Throughout the world, soil ecosystem has been contaminated with different types of heavy metals by various human activities and movement of metals in food chain has become human health hazard (Zahir et al., 2009). Cadmium is a $67^{\text {th }}$ most abundant element which has a density of $8.64 \mathrm{~g} / \mathrm{cm}^{3}$ at $20^{\circ} \mathrm{C}$, a melting point of $320^{\circ} \mathrm{C}$, and a boiling point of $767^{\circ} \mathrm{C}$. It is a silver-white, lustrous and ductile metal. The atomic number is 48 and atomic mass is 112.4 (Merian, 2004). Major groups of heavy metals including $\mathrm{Cd}$ have been shown in Table 1 .

Table 1. Major groups of heavy metals

\begin{tabular}{|c|c|c|}
\hline Major groups & Heavy metals & Reference \\
\hline Less toxic & Tin $(\mathrm{Sn})$ and Aluminum $(\mathrm{Al})$ & \multirow{3}{*}{ (Raikwar et al., 2008) } \\
\hline Highly toxic & Mercury $(\mathrm{Hg}), \mathrm{Lead}(\mathrm{Pb})$ and Cadmium $(\mathrm{Cd})$ \\
\hline Essential & $\begin{array}{c}\text { Copper }(\mathrm{Cu}), \mathrm{Zinc}(\mathrm{Zn}), \text { Cobalt }(\mathrm{Co}), \text { Chromium }(\mathrm{Cr}), \\
\end{array}$ & Manganese $(\mathrm{Mn})$ and Iron $(\mathrm{Fe})$ \\
\hline Non-essential & Barium $(\mathrm{Ba})$, Aluminum $(\mathrm{Al})$, Lithium $(\mathrm{Li})$ etc. & \\
\hline
\end{tabular}

Among the highly toxic metals, cadmium is one of the most important to consider because of its potential to enter into the human food-chain and its ability to accumulate in organs (ATSDR, 2008b). The most recent study suggests that around 300,000 USA workers involved in various cadmium based industries were estimated to be at elevated risk of cadmium exposure (ATSDR, 2008b). The increased emissions of cadmium resulting from various sources, combined with its persistence in the environment, and its relatively rapid uptake in crops, combine to make cadmium the fifth most toxic metal to animals and the fourth most toxic metal to plants (Muneer et al., 2011). The average concentration of cadmium in the lithosphere (crust and uppermost solid mantle) is $0.098 \mathrm{mg} / \mathrm{kg}$ (Heinrichs et al., 1980). In USA, around 300,000 workers involve in $\mathrm{Cd}$ based industries were estimated to be elevated risk of $\mathrm{Cd}$ exposure (ATSDR, 2008b). Cd is also present as an 
impurity in several products, including phosphate fertilizers, detergents and refined petroleum products, metal based pesticides, industrial emissions, transportation, harvesting process (Ali et al., 2013).

\section{Unsafe food in the world}

Food adulteration has become a global issue and the problem is not ignoring the human rights for safer food. Various kinds of food are commonly adulterated include fruit, vegetables, milk, fishes, sweet mates, rice, wheat, meat, soft drink, juice powder, baby and so on (Mahfuz, 2014). The problem of adulteration persists at every level of food from preparation to consumption. Most of the food manufactures and restaurant owners and also so forth are all involved in this unethical practice of adulteration. Foods are adulterated by using several exaggerated chemicals and toxic artificial colors. Fig. 1 shows the pathways of our food being contaminated.



Fig. 1. Pathways of unsafe food in the world

Addle and perishables foods are stored, sold and serve to consumers. Uses of poisonous chemicals in perishable foods are explicit in highest degrees which are endangering the lives of the people (Derek, 2015). Our future generation will be seriously affected with vulnerable physical and mental growth inflicted by food adulteration.

\section{Cd concentration of soils in Bangladesh}

The amount of $\mathrm{Cd}$ in soils depends on various factors such as soil components and the amounts added in the soil over time through atmospheric deposition etc. (Flora et al., 2011). Soil pH and organic matter also influence
Cd accumulation (Kirkham, 2006). Studies suggest that soil $\mathrm{pH}$ decreases the amount of $\mathrm{Cd}$ intake by the plants increases (Page et al., 1987). The highest total Cd was found to be $3.15 \mathrm{\varepsilon g} / \mathrm{g}$ in Chorfasion (Bhola) and it was followed by Ishardi (5.23 $\mathrm{\varepsilon g} / \mathrm{g})$, Kaligonj(2.89 $\mathrm{\varepsilon g} / \mathrm{g}$ ), Lalpur (2.39 عg/g), Dumuria (2.4 عg/g) and Asasuni(2.43 $\varepsilon \mathrm{g} / \mathrm{g})$. The lowest $\mathrm{Cd}$ value was found $1.38 \mathrm{\varepsilon g} / \mathrm{g}$ in Tangail Sadar which was identical to Botiaghata (1.51 $\varepsilon \mathrm{g} / \mathrm{g}$ ) and Madhupur (1.64 عg/g) (Akter et al., 2013). Table 2 shows the heavy metal concentrations of Bangladesh.

Table 2. Heavy metal concentrations $(\mu \mathrm{g} / \mathrm{g})$ in the collected soil samples of different areas of Bangladesh (Begum et al., 2014)

\begin{tabular}{|c|c|c|}
\hline Heavy metals & Dhaka City Area (Sultana, 2010) & Industrial Sites of Gazipur (Sumi, 2010) \\
\hline $\mathrm{Pb}$ & 3.84 & 12.00 \\
\hline $\mathrm{Ni}$ & $<0.002$ & 100.0 \\
\hline $\mathrm{Cr}$ & 32.25 & 0.20 \\
\hline $\mathrm{Cd}$ & 0.52 & 0.20 \\
\hline
\end{tabular}


The Cd concentrations were found in the soils of Dhaka Aricha highway, Savar, Bangladesh $3.99 \pm 1.85 \mathrm{mg} / \mathrm{Kg}$ (Aktaruzzaman et al., 2013). The $\mathrm{Cd}$ concentrations were found 0.32 to $0.54 \mathrm{mg} / \mathrm{kg}$ in tannery effluent contaminated soil in Dhaka (Mottalib et al., 2016). The $\mathrm{Cd}$ concentrations were found $0.49-4.89 \mathrm{mg} / \mathrm{kg}$ in surface soils of Chittagong city (Alamgir et al., 2015). The Cd concentrations were found $0.005-0.055 \mathrm{mg} / \mathrm{kg}$ in sediments of six freshwater wetlands of greater Dhaka district (Alam et al., 2018). The Cd concentrations were found ranged from 2.33 to $1.5 \mathrm{mg} / \mathrm{kg}$ and 0.75 to 2.10 $\mathrm{mg} / \mathrm{kg}$ in dry and wet season, respectively at Hazaribagh area (Mondol et al., 2017). The Cd concentration values of all soil samples were found to be ranged in between 1.07 to $1.5 \mathrm{mg} / \mathrm{kg}(0-15 \mathrm{~cm})$ and 0.567 to $0.933 \mathrm{mg} / \mathrm{kg}$ $(16-30 \mathrm{~cm})$. The mean values of $\mathrm{Cd}$ concentration were recorded 1.25 and $0.71 \mathrm{mg} / \mathrm{kg}$ at the top soils and subsoils, respectively. The highest value of $\mathrm{Cd}$ (1.5 $\mathrm{mg} / \mathrm{kg}$ ) was observed in the agricultural land where spinach was grown and the lowest concentration of $\mathrm{Cd}$ $(0.57 \mathrm{mg} / \mathrm{kg})$ was observed agricultural land where potato was grown (Saha and Hossen, 2018).

\section{Cd concentration of different vegetables in Bangladesh}

Vegetables are part of daily diets in many households forming an important source of vitamins and minerals required for human health (Thomson and Kelly, 1990). The daily vegetable consumption by an adult of Bangladesh is $130 \mathrm{~g}$ (Islam et al., 2005). The concentrations of these trace elements in vegetables may vary depending on the inherent (varieties, maturity, genetics, and age) and environmental (soils, geographical locations, season, water source and use of fertilizers) conditions of plants and animals and on methods of handling and processing (Pennington and Calloway, 1973). An average man accumulates as about $30 \mathrm{mg} \mathrm{Cd}$ in his body by the age of 50 years. Refined foods, water foods, water pipes, coffee, tea, coal burning and cigarettes are the most important source of $\mathrm{Cd}$ (Raikwaret al., 2008). In 1989, the FAO/WHO Joint Expert Committee on Food Additives (JECFA) set the Provisional Tolerable Weekly Intake (PTWI) for cadmium at $7 \varepsilon \mathrm{g} / \mathrm{kg} /$ week, corresponding to $1 \varepsilon \mathrm{g} / \mathrm{kg} / \mathrm{day}$ (WHO, 1989). Fig. 2 shows the heavy metal concentrations in vegetables in Bangladesh.



Fig. 2. Heavy metal (H) concentration of vegetables in the industrial area of Bangladesh (Ahmed et al., 2018)

The Cd concentrations were found $<0.1 \mathrm{mg} / \mathrm{kg}$ in potato, amaranths, spinach amaranths, carrot, cabbage, tomato, and brinzal at Pakshi union, Ishwardi, Pabna (Tasrina et al., 2015). The average $\mathrm{Cd}$ concentrations were found in amaranths, radish and cauliflower $2.545 \mathrm{mg} / \mathrm{kg}$ at Ruppur, Pabna district (Jolly et al., 2013). The Cd concentration in leafy vegetables (Red spinach) was found $0.180-2.305 \mathrm{mg} / \mathrm{kg}$ along the Dhaka Aricha Highway, Savar (Aktaruzzaman et al., 2013). The largest number of Bangladeshi food and non-food samples investigated for their $\mathrm{Cd}$ content. High $\mathrm{Cd}$ levels were detected in leafy vegetables (mean 31 [SD 29] $\varepsilon \mathrm{g} / \mathrm{kg}$ ). Of these vegetables, lalshak (Amaranths tricolor) contained the highest Cd level (303 $\varepsilon \mathrm{g} / \mathrm{kg}$ [wet weight]; mean 100.5 [SD 95] $\varepsilon \mathrm{g} / \mathrm{kg}$ ) (Al $\square$ Rmalli et al., 2012). The cadmium level (dry wt.) was the highest in spinach with a range of 0.559 to $1.400 \mu \mathrm{g} / \mathrm{g}$ followed by tomato with a range of 0.630 to $1.303 \mu \mathrm{g} / \mathrm{g}$ and cauliflower having 0.506 to $0.782 \mu \mathrm{g} / \mathrm{g}$ (Naser et al., 2009). In Porabari union, Tangail; the $\mathrm{Cd}$ concentration values of all vegetables sample were found to be ranged in between 0.053 to $0.143 \mathrm{mg} / \mathrm{kg}$. The highest value of $\mathrm{Cd}$ concentrations in vegetables $0.143 \mathrm{mg} / \mathrm{kg}$ in (Amaranths) land and the lowest value of cadmium concentration in vegetables were $0.053 \mathrm{mg} / \mathrm{kg}$ in (Cauliflower and Zucchini) land (Saha and Hossen, 2018). 


\section{Cd concentration in rice in Bangladesh}

Heavy metal contamination in paddy soils is one of the most serious problems facing rice production and soil management in Asian countries. In the world, especially in Latin America, the East, and South Asia, the Middle East and the West Indies rice is one of the most important staple foods which are the staff of life for 3 billion people (Stone, 2008). It also provides about 30\% of the dietary energy and $20 \%$ of the dietary protein in Asia (WHO, 2002). However, rice may contain significant amounts of contaminants such as arsenic
(As), cadmium (Cd) and lead (Pb) (Meharg et al., 2013). The irrigated rice samples collected from Mymensingh exhibited the highest $\mathrm{Cd}$ concentration (mean 0.080 $\mathrm{mg} / \mathrm{kg})$, which was threefold higher than Saltha $(0.024$ $\mathrm{mg} / \mathrm{kg}$ ) and between the two rice seasons, the difference of $\mathrm{Cd}$ concentration was small and also the Cd level of rice samples depending on the varieties ranged from $0.007-0.297 \mathrm{mg} / \mathrm{kg}$; however, the majority varieties had Cd concentration below $0.05 \mathrm{mg} / \mathrm{kg}$ (Jahiruddin et al., 2017). Table 3 shows the maximum permissible level of heavy metals in rice.

Table 3. Maximum permissible Level (MPL) of heavy metal in rice (Magamage et al., 2017)

\begin{tabular}{|l|l|l|l|l|l|}
\hline Metal Type & $\mathrm{As}$ & $\mathrm{Cd}$ & $\mathrm{Pb}$ & $\mathrm{Hg}$ & $\mathrm{Se}$ \\
\hline MPL (ppm) & 0.2 & 0.2 & 0.2 & 0.1 & 0.3 \\
\hline
\end{tabular}

The Cd levels over 260 rice samples across 12 districts of Bangladesh in the range of $<0.005-1.31 \mathrm{mg} / \mathrm{kg}$, with the mean of $0.099 \mathrm{mg} / \mathrm{kg}$ (Meharg et al., 2013). In the study of Bangladesh Rice Research Institute (BRRI) they found that 8/86 samples of industrial field rice were highly contaminated with cadmium $(>0.07 \mathrm{mg} / 416.01 \mathrm{~g})$ and they also found 21/76 market samples of rice contained greater amount than the risk level of daily intake of cadmium (Hezbullah et al., 2016). The Cd concentration of rice grain showed significant difference among various contaminated soils. The mean $\mathrm{Cd}$ values in rice grains were $0.98,0.10,0.22$ and $0.36 \mathrm{mg} / \mathrm{kg}$ dry weight for city sewage; tannery, fertilizer factory and cement factory soil, respectively. The Cd concentration in straw and root also varied significantly among the soils. The $\mathrm{Cd}$ concentration ranged from 2.73 to 6.91 $\mathrm{mg} / \mathrm{kg}$ in straw and 3.50 to $27.91 \mathrm{mg} / \mathrm{kg}$ in root (Kibria, 2012) reported that. The $\mathrm{Cd}$ concentration of four rice varieties (Minicat, BRRI 28, BRRI 29, Swarna) from field and market were found between 2.93-5.67, 3.669.55, 0.16-0.57, 0.19-0.93 mg/kg respectively (Uddin et al., 2017). In Porabari union, Tangail; the $\mathrm{Cd}$ concentration values of all rice (BRRI 28) samples were found to be ranged in between 0.057 to $0.097 \mathrm{mg} / \mathrm{kg}$ and also the mean values of $\mathrm{Cd}$ concentration in rice were recorded at $0.071 \mathrm{mg} / \mathrm{kg}$ (Saha and Hossen, 2018) (Fig. $3)$.

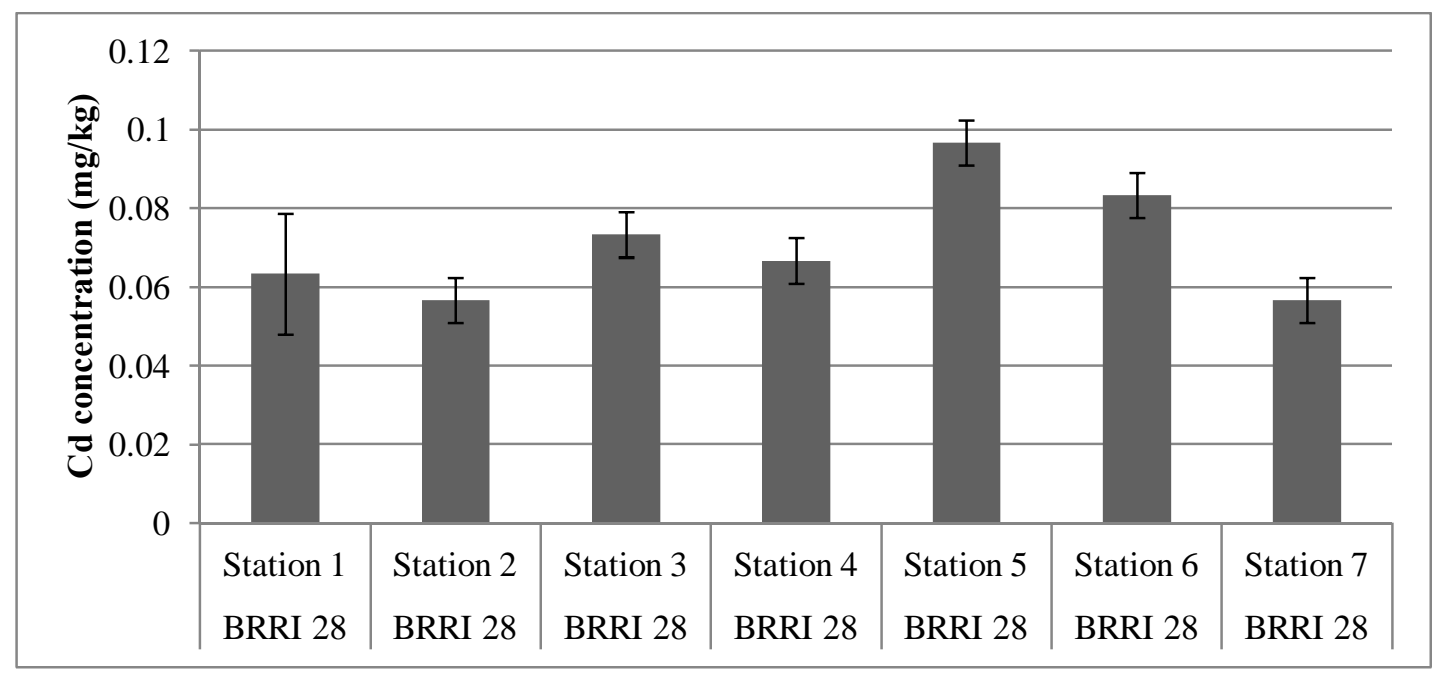

Fig. 3. Cadmium (Cd) concentrations in Rice at Porabari Union, Tangail (Saha and Hossen, 2018) 
Number of kidney patients and dialysis expenditure in Bangladesh

Around 20 million people currently suffer from kidney disease in Bangladesh and among which 800,000 require dialysis (Farhin, 2017). One in every seven people in the country has been suffering from kidney diseases and 40,000 die of longtime kidney failures annually (The Daily Star, 2019) and also reported that the rate of chronic kidney disease has now increased to 18 percent from 9 percent during the period (The Daily Star, 2019). National Health Bulletin 2016 showed that among the top causes of death at medical college hospitals in 2015, kidney disease was placed sixth. The government run dialysis centres take Tk 400 for a single dialysis, but the facilities are not adequate and also a single dialysis costs about Tk 1,600-5,000 at private facilities, while a patient need two-three dialysis in a week. According to Kidney Foundation, against the yearly need of 20,000 kidney transplantations, about 100 kidneys are transplanted in the country a year (Kabir, 2019).

\section{Effects of Cd on human health}

Cadmium is denominated mostly for its high toxicity to animals and humans (Merian, 2004). Cadmium has a biological half-life between 15-30 years, which causes its accumulation in the blood, kidney, liver, and the reproductive organs (Flora et al., 2011). Fig. 4 shows the Transfer of Cadmium in the human food chain and its health effect.

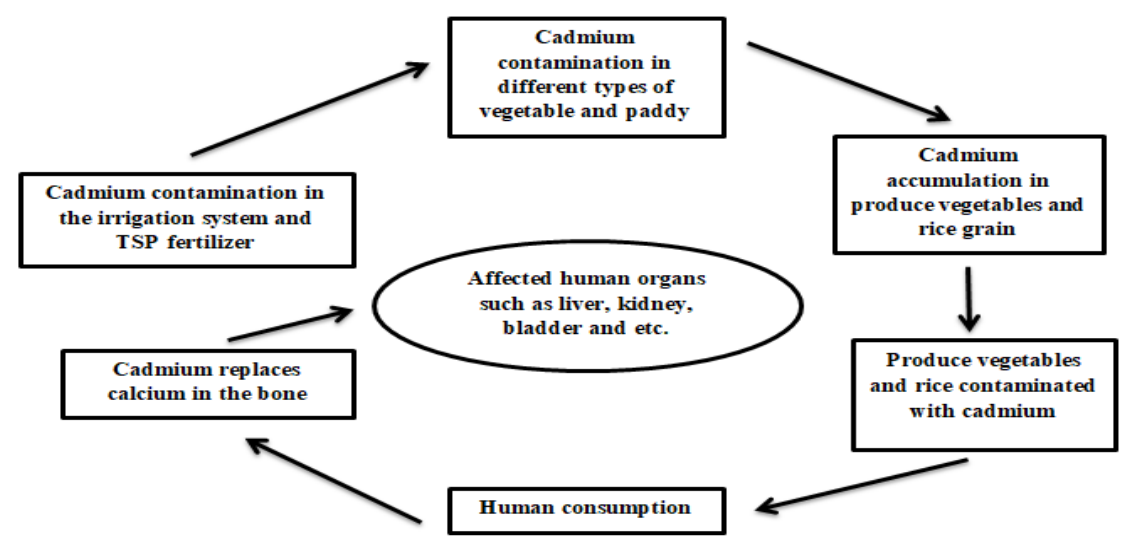

Fig. 4. Transfer of Cadmium in the human food chain and its health effect

Sewage sludge or household leachate used for irrigation and it also increases the average $\mathrm{Cd}$ in soil and different types of vegetable (Gholamiet al., 2011). It causes various health-related problems in humans through accumulation in different organs. Cd enters through ingestion and inhalation in the human body (Cadmium Working Group, 2011b). The acute effects of this metal can be seen in the respiratory and digestive tracts (Merian, 2004). The toxic effects of excess $\mathrm{Cd}$ on humans are hypertension, emphysema, carcinogenic changes (mainly kidney and prostate), skeletal deformation and low reproductive function (KabataPendias and Mukherjee, 2007). Cadmium exposure may increase important manifestations of cardiovascular disease Environmental exposure to $\mathrm{Cd}$ is associated with significantly increased stroke and heart failure prevalence(Peters et al., 2010). The Environmental Protection Agency (EPA) has established maximum containment levels for cadmium in drinking water at 5 $\mu \mathrm{g} / \mathrm{l}$ (ATSDR, 2008).

\section{Conclusions}

Cadmium concentration in Bangladesh soils and rice has been observed higher than the permissible limits. The source of $\mathrm{Cd}$ in soils and rice are mostly from industrial activities and triple super phosphates used in agricultural lands. The number of kidney patients is increasing in Bangladesh. We assume that this might be due to the high concentration of $\mathrm{Cd}$ in foods which are consumed by the inhabitants. Bangladesh is spending a large amount of money for kidney patients. If proper awareness program and action could be taken, this could discourage people to apply excessive phosphate fertilizers to soils. This will reduce the excessive intake of $\mathrm{Cd}$ by human being. Further lab works are warranted to find out the way of reducing the input of $\mathrm{Cd}$ in agricultural soils. 


\section{References}

Ayoub, A.T., 1999. Fertilizers and the environment. Nutrient Cycling in Agroecosystems, 55(2), pp.117-121.

Ali S, Sardar K, Hameed S, Afzal S, Fatima S, Shakoor BM, Tauqeer HM (2013). Heavy metals contamination and what are the impacts on living organisms. Greener J. Environ. Manage. Public Saf. (2):172-179.

ATSDR, 2008. Cadmium, Agency for Toxic Substances and Disease Registry, Public Health Statement, May, Vol. Public. Washington, D.C.

Ahmed, M., Matsumoto, M. and Kurosawa, K., 2018. Heavy Metal Contamination of Irrigation Water, Soil, and Vegetables in a Multi-industry District of Bangladesh. International Journal of Environmental Research, 12(4), pp.531-542.

Akter, M., Chowdhury, A.K., and Chowdhury, M.A.H., 2013. Soil organic matter, mineral nutrients, and heavy metals status of some selected regions of Bangladesh. Journal of Environmental Science and Natural Resources, 5(2), pp.01-09.

Aktaruzzaman M, Fakhruddin ANM, Chowdhury MAZ, Fardous Z, Alam, MK (2013). Accumulation of Heavy Metals In Soil And Their Transfer To Leafy Vegetables In The Region Of Dhaka Aricha Highway, Savar, Bangladesh. Pak. J. Biol. Sci.16 (7):332.

Alamgir, M., Islam, M., Hossain, N., Kibria, M.G. and Rahman, M.M., 2015.Assessment of heavy metal contamination in urban soils of Chittagong City, Bangladesh. Intl J Plant Soil Sci, 7(6), pp.362-372.

Alam, A.R., Hossain, A.B.M., Hoque, S. and Chowdhury, D.A., 2018. Heavy Metals in Wetland Soil of Greater Dhaka District, Bangladesh. Pollution, 4(1), pp.129-141.

Aktaruzzaman, M., Fakhruddin, A.N.M., Chowdhury, M.A.Z., Fardous, Z. and Alam, M.K., 2013.Accumulation of heavy metals in soil and their transfer to leafy vegetables in the region of Dhaka Aricha Highway, Savar, Bangladesh. Pak. J. Biol. Sci, 16(7), pp.332338.

Al $\square$ Rmalli, S.W., Jenkins, R.O. and Haris, P.I., 2012. Dietary intake of Cadmium from Bangladeshi foods. Journal of Food Science, 77(1), pp.T26T33.

BBS (Bangladesh Bureau of Statistics), 2006. Statistical Pocketbook of Bangladesh (2006); Statistics
Division, Ministry of Planning, Government of the Peoplese Republic of Bangladesh, Dhaka, Bangladesh.

Begum, K., Mohiuddin, K.M., Zakir, H.M., Rahman, M.M. and Hasan, M.N., 2014. Heavy metal pollution and major nutrient elements assessment in the soils of Bogra city in Bangladesh. Canadian Chemical Transactions, 2(3), pp.316-326.

Cadmium Working Group. (2011b) Cadmium and New Zealand Agriculture and Horticulture: A Strategy for Long-Term Risk Management, Ministry of Agriculture and Forestry, Wellington.

Derek, L., 2015. Eight toxic foods: a little chemical education,

https://blogs.sciencemag.org/pipeline/archives/2 013/06/21/eight_toxic_foods_a_little_chemical _education.

Flora, J.S.S., Pachauri, V., and Saxena, G., 2011. Arsenic, Cadmium and Lead. Reproductive and developmental biology, Chapter 33. 415-438.

Farhin, N. 2017. Kidney dialysis at Tk800. Published at 05:36 pm October 26th, 2017, Dhaka Tribune. Available online: https://www.dhakatribune.com/feature/healthwellness/2017/10/26/kidney-dialysis-tk-800.

Gholami A., Ahmadi S., Panahpour E. (2011). The effect of using compost leachate on soil reaction and soil cadmium absorption.Advances in Environmental Biology 5:3102- 3109.

Hezbullah, M., Sultana, S., Chakraborty, S.R. and Patwary, M.I., 2016. Heavy metal contamination of food in a developing country like Bangladesh: An emerging threat to food safety. Journal of Toxicology and Environmental Health Sciences, 8(1), pp.1-5.

Heinrichs, H., Schulz-Dobrick, B., and Wedepohl, K.H., 1980.Terrestrial geochenistry of Cd, Bi, Ti, Pg, $\mathrm{Zn}$, and $\mathrm{Rb}$. GeochimicaCosmochimicaActa 44, 1519-1532.

Islam, M.R., Hoque, M.E., Jahiruddin, M. and Islam, S., 2005. Heavy metal contamination of vegetables grown in Chapai-Nawabganj, Bangladesh and its implication to daily intake for human health. Bangladesh J. Agric. Environ, 1(1), pp.37-47.

Jahiruddin, M., Xie, Y., Ozaki, A., Islam, M.R., Nguyen, T.V. and Kurosawa, K., 2017.Arsenic, cadmium, lead and chromium concentrations in irrigated and rain-fed rice and their dietary 
intake implications. Australian Journal of Crop Science, 11(7), p.806.

Jolly YN, Islam A, Akbar S (2013). Transfer of metals from soil to vegetables and possible health risk assessment. Springer Plus 2(1):18.

Kibria, M.G (2012). Uptake of Cadmium and Lead by Rice Grown in Four Contaminated Soils of Chittagong, Bangladesh. HamdardMedicus, Vol. 55, No. 2, 2012.

Kirkham, M.B., 2006. Cadmium in plants on polluted soils: effects of soil factors, hyper accumulation, and amendments. Geoderma, 137(1-2), pp.1932.

Kabata-Pendias, A. and Mukherjee, A.B., 2007. Trace elements from soil to human. Springer Science $\&$ Business Media.

Meharg, A.A., Norton, G., Deacon, C., Williams, P., Adomako, E.E., Price, A., Zhu, Y., Li, G., Zhao, F.J., McGrath, S. and Villada, A., 2013.Variation in rice cadmium-related to human exposure. Environmental science \& technology, 47(11), pp.5613-5618.

Merian, E., Anke, M., Ihnat, M. and Stoeppler, M., 2004. Elements and their compounds in the environment: occurrence, analysis and biological relevance (No. Ed. 2).Wiley-VCH Verlag GmbH \& Co. KGaA.

Muneer, S., Qadri, T.N. and Siddiqi, T.O., 2011. Cytogenetic and biochemical investigations to study the response of Vignaradiata to cadmium stress. African Journal of Plant Science, 5(3), pp.183-192.

Mottalib, M.A. and Somoal, S.H., 2016. Md contaminated soil and vegetables of tannery area in Dhaka. Bangla Article History: Received 26th February.

Mahfuz, M. 2014. The Daily AmaderShomoy, 2 July, 2014. http://www.dainik-amadershomoy.com/

Mondol, M., Asia, A., Chamon, A. And Faiz, S., 2017. Contamination of Soil and Plant by theHazaribagh Tannery Industries.

Manohar, M., Shigaki, T., Shigaki, L., Hirschi, K.D., Bubia, L. and Guinea, P.N., Past, Present and Future Approaches for reducing Cadmium Content in Tobacco leaves.

Magamage, C., Waidyaratna, W., Dhanapala, W. and Panampitiya, D.M., 2017. Determination of Heavy Metals in Rice Available in Kandy District, Sri Lanka. Annals of Srilanka Department of Agriculture, 19, pp.351-368.
Naser, H.M., Shil, N.C., Mahmud, N.U., Rashid, M.H. and Hossain, K.M., 2009. Lead, cadmium and nickel contents of vegetables grown in industrially polluted and non-polluted areas of Bangladesh. Bangladesh Journal of Agricultural Research, 34(4), pp.545-554.

NurulKabir, 2019. Published by the Chairman, Editorial Board ASM Shahidullah Khan on behalf of Media New Age Ltd. 30 Tejgaon Industrial Area, Dhaka-1208 Phone: 880-2-8170450-56 (PABX), Fax: 880-2- 8170457.

National Convention and Scientific Seminar: One in seven suffers from kidney disease in Bangladesh. Published at Monday, July 29, 2019, The Daily Star. Available online: https://www.thedailystar.net/news-detail-65021.

Peters, J.L., Perlstein, T.S., Perry, M.J., McNeely, E. and Weuve, J., 2010. Cadmium exposure in association with the history of stroke and heart failure. Environmental research, 110(2), pp.199-206.

Pennington, J.T. and Calloway, D.H., 1973. Copper content of foods. Factors affecting reported values. Journal of the American Dietetic Association, 63(2), pp.143-153.

Page, A.L., Chang, A., C., and El-Amamy, M., Cadmium levels in soils and crops in the United States, in: Meema, T. C. H. a. K. M., (Ed.), Lead, Mercury, Cadmium and Arsenic in the Environment, Published on behalf of the Scientific Committee on Problems of the Environment (Scope) of the International Council of Scientific Unions (ICSU) by Wiley, Chichester; New York 1987, pp. 119-146.

Raikwar MK, Kumar P, Singh M and Singh A (2008). Toxic effect of heavy metals in livestock health. Vet. World 1(1):28-30.

Rahman SH, Khanam D, Adyel TM, Islam MS, Ahsan MA and Akbor MA (2012). Assessment Of Heavy Metal Contamination Of Agricultural Soil Around Dhaka Export Processing Zone (DEPZ), Bangladesh: Implication Of Seasonal Variation And Indices. Appl. Sci. 2(3):584-601.

Ratul, A.K., Hassan, M., Uddin, M.K., Sultana, M.S., Akbor, M.A. and Ahsan, M.A., 2018. Potential health risk of heavy metals accumulation in vegetables irrigated with polluted river water. International Food Research Journal, 25(1). 
Stone, R., 2008. Arsenic and paddy rice: a neglected cancer risk?

Sultana, N., 2010. Nutrition content and heavy metal contamination in some roadside soils and grasses of Dhaka City, Bangladesh. MS Thesis, Department of Agricultural Chemistry, Bangladesh Agricultural University, Mymensingh.

Sumi, S.A., 2010. Toxic metallic contamination in industrial wastewater and soils of some selected areas of Gazipur, Bangladesh. M. Sc. (Ag.) thesis, Department of Agricultural Chemistry, Bangladesh Agricultural University, Mymensingh.

Saha, S., and Hossen, M.K.,2018. Status of Cadmium Concentration in Soils, Vegetables, Rice and Fertilizers of Porabari Union, Tangail, Bangladesh. B. Sc. (Hons) Thesis. Department of Environmental Science and Resource management, Mawlana Bhashani Science and Technology University, Tangail.

Thompson, H. C. and W. C. kelly, 1990. Vegetable Crops. New Delhi: McGraw Hill publishing company.

Tasrina, R.C., Rowshon, A., Mustafizur, A.M.R., Rafiqul, I. and Ali, M.P., 2015. Heavy metals contamination in vegetables and its growing soil. J Environ Anal Chem, 2(142), p.2.
Uddin, R., Biswas, G., Paul, D.K., Khatun, N. M., Alam, F.M., Huque, R., and Munshi, K. M., 2017. Study on trace elements of popular rice varieties in Bangladesh. Int. J. Biosci. 11(4), 237-246, October 2017.

Wild, A. 1996. Soils and the environment: An introduction. Cambridge University Press, p. 13.

WHO, 1989. Evaluation of Certain Food Additives and Contaminants (Thirty-third Report of the Joint FAO/WHO Expert Committee on Food Additives). WHO Technical Report Series No. 776. Geneva: World Health Organization. Available at: http://apps.who.int/iris/bitstream/10665/39252/1 /WHO_TRS_776.pdf

World Health Organization Staff, World Health Organization. Food Safety Programme, FAO., World Health Organization, WHO and Food Safety Programme, 2002. Health Implications of Acrylamide in Food: Report of a Joint FAO/WHO Consultation, WHO Headquarters, Geneva, Switzerland, 25-27 June 2002. World Health Organization.

Zahir, E., Naqvi, I.I. and Uddin, S.M., 2009. Market basket survey of selected metals in fruits from Karachi city (Pakistan). Journal of Basic and Applied Sciences, 5(2), pp.47-52. 